\title{
Çeşitli Bitki Ekstraktlarının Çiğ köfte Üzerindeki Antimikrobiyal Etkisi
}

\author{
Simge Nur KESKİN*, Ebru ŞİN, Gökhan AKARCA, Oktay TOMAR \\ Afyon Kocatepe Üniversitesi, Mühendislik Fakültesi, Grda Mühendislï̆i Bölümü, Afyonkarahisar \\ *Corresponding author e-mail: simgenur_keskin@hotmail.com
}

\begin{abstract}
ÖZ
Çiğ köfte günlük olarak hazırlanıp, birkaç saat içerisinde tüketilmesi gereken, raf ömrü kısa ve mikrobiyal açıdan riskli bir gıdadır. Bu araştırmada; çiğ köfte numunelerine belirli oranlarda değişik baharat ekstrakları ilave edilmesinin, çiğ köftelerin raf ömrü üzerine etkisi etkileri incelenmiştir. Çalışmada kullanılacak çiğ köfte hazırlandıktan sonra, \%0,5 ve \%1 oranında bitki ekstraktları (yeşil çay, hibiskus, tarhun, ceviz kabuğu, limon kabuğu yağı, portakal kabuğu yağı) ilave edilerek $+4^{\circ} \mathrm{C}$ de 21 gün süreyle depolanmıştır. Depolamanın $0,7,14$ ve 21. günlerinde, Lactobacillus spp., Lactococcus spp., maya ve küf, Psendomonas spp., Eschericbia coli, , Staphylococcus aureus, toplam koliform, Listeria spp., Salmonella spp., toplam aerobik mezofilik ve toplam aerobik psikrofilik mikroorganizma varlığı araștırılmış; ayrıca depolama süresince, baharatların çiğ köftenin rengine etkisi de incelenmiştir. Depolama süresi boyunca numunelerin sırasıyla parlaklık-koyuluk, kırmızı-yeşil ve sarı-mavi renk göstergesi olan; $L^{*}, a^{*}$ ve $b$ değerlerinde artış gözlenmiştir. Yapılan mikrobiyolojik analiz sonuçlarına göre ise numunelerin hepsinde maya-küf sayıs1, Psendomonas cinsi bakteri sayıs1, laktik asit bakteri sayısı ve Lactococcus cinsi bakteri sayılarında azalma görülürken; toplam aerobik mezofilik bakteri sayısında kullanılan ekstrakta göre farklillk gözlemlenmiş, patojen mikroorganizma ve Staphylococcus aureus cinsi bakterilerin üreme göstermediği tespit edilmiştir.
\end{abstract}

Anahtar Kelimeler: Çĭ̆ köfte, antimikrobiyal etki, baharat, ekstrakt, raf ömrü

\section{Antimicrobial Effect of Various Plant Extracts on Raw Meatballs}

\begin{abstract}
Raw meatballs is a food which should be prepared daily and consumed within a few hours, shelf life is short and microbial in terms of risk. This research was carried out with the aim of determining the effect of various spices and modification of raw meatballs on shelf life. The effects of the spice extracts on the shelf life were investigated by adding the spice extracts to the prepared raw meat ball samples at certain ratios. After preparing the raw meatballs to be used in the study, plant extracts (green tea, hibiscus, tarragon, walnut shell, lemon peel oil, orange peel oil) were added at the rates of $0,5 \%$ and $1 \%$ and stored at $+4{ }^{\circ} \mathrm{C}$ for 21 days. On days $0,7,14$ and 21 of storage; total aerobic mesophilic bacteria, yeast and mold, total coliform bacteria, Lactobacillus spp., Lactococcus spp., Psendomonas spp., Listeria spp., Salmonella spp. Escherichia coli and Staphylococcus aureus counts has been researched. In addition, the effect of the spice on the color of raw meatballs during storage was also examined. During the storage period; the samples were of brightness-darkness, red-green and yellow-blue color indicator, respectively; $\mathrm{L}^{*}, \mathrm{a} *$ and $\mathrm{b} *$ values were increased. According to the microbiological analysis results; yeast-mold count, Pseudomonas spp., lactic acid bacteria and Lactococcus bacteria counts decreased in all samples. In contrast, the total aerobic mesophilic bacterial counts differed according to the extract used. In addition, Listeria spp, Salmonella spp, Escheriscbia coli and Staphylococcus aureus were found not to reproduce.
\end{abstract}

Keywords: Raw meatball, antimicrobial effect, spice, extract, self life. 


\section{GİRIŞ}

Çiğ Köfte, Türkiye'de hazırlanan önemli geleneksel gidalardan birisi olup, aslen ülkenin doğu bölgelerine özgü bir üründür. Ancak son zamanlarda batısinda da yaygin olarak tüketilmektedir (Gezgin 2005).

Yapımı ve içeriği bölgesel olarak farklılıklar göstermesine karşın genel hammaddesi bulgur, tercihe bağlı olarak yağsız sığır kıyması, soğan, sarımsak, salça, maydanoz, tuz ve çeşitli baharatlardır. Çiğ köftenin yapımında kullanılacak malzemeler yoğrulup el ile şekil verilerek satışa sunulur. Tercihen küçük bir parça marul ve lavaşa sarılır, üzerine limon sıkılarak tüketilir. (Dağlıŏglu ve ark. 2005).

Ürünün üretiminde kullanılan hammaddeleri çoğunluğu k1yma ve bulgurdan gelen mikroorganizmalara ek olarak, üretim aşamasinda ilave edilen katk1 maddeleri, su, çiğ köfteyi hazırlayan personel ve üretim yapilan tesisin atmosferi dahil her türlü araç- gereç, bir çok riskli mikroorganizmayı içinde barındırmaktadır (Arslan ve ark. 1992, Başoğlu 1982, Çetin ve ark. 1985, Erol ve ark.. 1993, Sağun ve ark. 1997a, Sağun ve ark. 1997b).

Çiğ köftenin tüketim süresi, depolama koşullarına göre 1-2 gün arasındadır. Fakat formülasyonunda bulunan bileşenlerden kaynaklanan yüksek risk nedeniyle hazırlanışının ardından kısa süre içerisinde tüketilmesi tavsiye edilir (Öcal 1997). Ayrıca içerdiği hammaddelerin mikrobiyal yükü ve herhangi bir 1sıl işleme tabi tutulmaması nedeniyle de çiğ köfte, sağlık açısından da risk taşıyan bir gidadır (Gezgin 2005).

Çiğ köftelerin mikrobiyal güvenliği ile ilgili yapılmış çok sayıda çalışma mevcuttur. Pek çok araştırmacı tarafından çiğ köfte üretiminde kullanılan kıyma ve baharatlarda patojen bakteri suşları kontaminasyonu (Staphylococcus aureus, koliform bakteri, Eschericbia coli, Enterococci and Bacillus cereus) olduğu rapor edilmiștir (Erol ve ark. 1993, Tekinşen ve ark. 1980).

Konu ile ilgili olarak Tunçel ve Tiryaki (2001) çalışmalarında, piyasadaki çiğ köftelerde patojenik mikroorganizma varllğ1 araştırllmıştır. Elde edilen sonuçlara göre, numunelerin \%14' ünden Salmonella izole edilirken aynı zamanda çok sayıda koliform grubu bakteri de tespit edilmiştir.

Çiğ köftedeki bu koliform ve patojen bakterilerin çiğ etten, formülasyonda kullanılan diğer katk1 maddelerinden veya personelden kaynaklanmış olabileceği vurgulanmıştır.
Erol et al. (1993) yapmış olduğu çalışmada, çiğ köfteye katılan baharatların antimikrobiyal etkisinin olduğu düşünülmüş fakat bu etkinin Salmonella ya da diğer patojen mikroorganizmaları tamamen ortadan kaldırabilecek kadar etkili olmadığı kanısına varılmıștır. Gidalarda bulunabilecek bu mikroorganizmaları inhibe etmek, gelişimlerini yavaşlatmak ve gıdaların raf ömrünü daha uzun hale getirebilmek için çeşitli kimyasal maddeler kullanilmaktadır. Ancak son dönemde, sentetik antimikrobiyal maddelerin güvenirliğine ilişkin endişeler nedeni ile bitkisel ekstraktlar gibi doğal yolla elde edilen bileşiklerin gidalarda antimikrobiyal, antioksidan ve diğer çeșitli amaçlarla kullanımında bir artış söz konusudur. (Koca ve Bostanc1 2013).

Baharatların antioksidan ve antimikrobiyal Özelliklerinin araştırılması 1880'lerde başlayıp 20. yüzyıla kadar süregelmiştir. Yapılan araştırmalar baharat ekstraktları ve çeşitli esansiyel yağları da kapsayacak şekilde günümüzde de devam etmektedir. (Coggins 2001). Günümüzde baharatların esansiyel yağları ya da aktif bileşenleri, gidalarda mikrobiyal gelişimin ve oksidatif bozulmanın kontrolünde, kimyasallara karşı tercih edilen önemli bileşikler haline gelmiştir (Arın 2009). Günümüzde çeşitli çalışmalara konu olan yeşil çay yapraklarının antimikrobiyal etkilerinin varlığı, yapılan araştırmalar sonucunda ortaya konulmuştur. Yeșil çayın bașlıca fenolik bileșiklerinden olan kateşinlerin, kuvvetli antioksidan özellik göstermelerinin yanı sıra, gerek gidalarda bozulma yapan mikroorganizmalara, gerekse insanlarda hastalık etmeni olan patojen mikroorganizmalara karşı kuvvetli bir antimikrobiyal etki gösterdikleri de belirtilmiştir (Keskin ve ark. 2017). Amarowicz ve Shahidi (1996) tarafindan yapılan bir çalışmada, yeşil çay polifenollerinin Escherichia Coli K12 suşuna karș1 antibakteriyel etkisinin olduğu rapor edilmiştir.

Araştırmacilar tarafindan antimikrobiyal etkisi ortaya konulan diğer bir bitki ise Hibiscus sabdiriffa? dir. Malvaceae familyasına dahil, tek y1lltk otsu bir bitki olan hibiskus bitkisi, hayvan yemi ve lif üretimi gibi çeşitli amaçlar ile yetiştirilmesinin yanı sıra yapraklarının çaya benzer șekilde demlenmesi ile içecek olarak da tüketilmektedir. (Plotto ve ark. 2004). Bunun dişında hibiskus bitkisi kimyasal zehirlenmeler ve mantar zehirlenmelerinde antidot olarak da kullanılmaktadır (Şen 2011). Ayrıca hibiskus bitkisinin antimikrobiyal etkisinin olduğu, çeşitli çalışmalar sonucu ortaya konulmuştur. Fullerton ve ark. (2011) tarafindan yapilan bir çalışmada, antibiyotiğe karşı dirençli olan Campylobacter suşları ile kontamine olmuş et sularında, agar yüzeyine hibiskus ekstraktı 
uygulamasıyla suşların gelişiminin etkili bir şekilde engellendiği rapor edilmiştir.

Tarhun (Artemisia dracunculus L.) tıbbi ve aromatik amaçlı yayg1n olarak kullanılan ve çeşitli çalışmalar ile antimikrobiyal özelliği ile bilinen bitkilerden birisidir (Azırak 2007). Artemisia dracunculus L. bitkisinin antimikrobiyal özelliklerinin de incelendiği bir çalışmada, bu bitkinin uçucu yağlarının antimikrobiyal aktiviteye sahip olduğu yapilan analizler sonucunda ortaya konulmuştur. (Tüylü ve ark. 2009).

Esansiyel yağlar da Gram (-) ve Gram (+) bakteriler dahil, çeşitli mikroorganizma üzerinde antibakteriyel etkiye sahiptir (Bayaz 2014). Araştırmalar sonucunda limon ve portakal kabuğu yağlarının da içerisinde bulunduğu çok çeşitli bitkisel uçucu yağların antimikrobiyal etkiye sahip olduğu ortaya konulmuştur (Karanki 2013).

Ceviz yeşil kabuk ve yaprak kısımları da geleneksel tedavi yöntemlerinde halk arasinda kanama durdurucu, damar kuvvetlendirici, , antihelmintik, antidiaretik, hipoglisemik, hipotansiv, sedativ buna ek olarak antifungal özellikleri ile bilinmekte ve kullanılmaktadır. Değişik çalışmalarda cevizin özellikle ağaç kabuğu, yaprak, yeşil meyve kabuğu ve juglon maddesinin antimikrobiyal aktivitesi olduğu belirlenmiştir (Yiğit ve ark. 2009).

$\mathrm{Bu}$ çalışmada çeşitli mikroorganizmalar üzerinde inhibe edici özellik gösterebileceği ön görülen bitki ekstraktları, çiğ köfteye değişik oranlarda ilave edilmiş ve mikroorganizma türlerinin raf ömrü boyunca gelişimi gözlenmiştir.

\section{MATERYAL ve METOT}

Çiğ köfte, Öcal (1997)'ın belirttiği formülasyon modifiye edilerek Tablo.1 de belirtildiği oranlarda karıştırılarak etsiz olarak hazırlanmıştır. Çiğ köftenin yapımında kullanılan hammaddelerin temini Afyonkarahisar İ Merkezi'ndeki bir satış noktasından temin edilmiştir. Bitkilerden ekstrakt eldesi amaciyla Karakoç ve Gökçe (2013) tarafından belirtilen yöntem referans alınmıştır. Bu yönteme göre her bitki materyalinden 50 gr tartılıp 1000 ml' lik erlenmayerlerin içerisine konulmuştur. Sonrasinda bitkilerin üzerine $500 \mathrm{ml} \% 80$ ' lik etanol eklenmiştir. Bu karışımın üzeri alüminyum folyo ile ile kapatilarak erlenmayerler, 24 saat boyunca shaker (WiseShake ®SHO-2D) kullanılarak 120 rpm' de karıştırılmıştır. Bu süre sonunda karışımlar süzgeç kağıdından (Whatman ( ) Grade 40) süzülerek, süzüntü içerisinde bulunan alkol, rotary evaporatör (Heidolph Hei- VAP value) kullanılarak $120 \mathrm{rpm}$ de $60^{\circ} \mathrm{C}$ de sıcaklıkla ayrılmıştır (Karakoç ve Gökçe 2013). Hazırlanan çiğ köfte 250 şer gram olmak üzere toplam 13 adet steril numune kaplarına alınmıştır. 1 adet kontrol olmak şartıyla, her bir ekstrakttan $\% 0,5$ ve $\% 1$ oranlarinda numunelere ilave edilmiştir. Kontrol numunesi ve ekstrakt ilave edilen numuneler 21 gün süre ile $+4^{\circ} C^{\prime}$ de muhafaza edilmiştir. Muhafaza süresince $0,7,14$ ve 21. günlerde mikrobiyolojik ve fizikokimyasal analizleri yapılmıştır.

Baharat ekstraktları ilave edilmiş çiğ köfte numunelerinden, steril numune kaplarına 250 gram alınarak, analizi yapilincaya kadar $4^{\circ} \mathrm{C}$ de muhafaza edilmiştir. Numunelerden steril numune kaşığı yardımı ile 10 gram alınarak steril numune poşetlerine aktarılmış ve üzerinde $90 \mathrm{ml}$ steril ringer çözeltisi ilave edilmiştir. Numunenin homojen hale gelmesi için stomacher cihazında (BagMixer® 400 P-080921247) iyice karışması sağlanmıştır. Hazırlanmış olan bu $10^{-1^{\prime}}$ lik dilüsyondan steril pipet ile $1 \mathrm{ml}$ alınarak tüm numunelerin dilüsyonları hazırlanmıştır.

Ardından, hazırlanmış olan 10-1'lik dilusyondan steril otomatik pipet yardımı ile $1 \mathrm{ml}$ alınarak, içerisine önceden $9 \mathrm{ml}$ steril ringer çözeltisi konulan ağzı kapalı steril deney tüplerine aktarılmış ve $10^{-2}$ lik diüsyon hazırlanmıştır. İşlemlere aynı şekilde devam edilerek, $10^{-3}$ ve $10^{-4}$ 'lük dilusyonlar elde edilmiştir (Anonim 1998, Seçkin ve Karagözlü 2004, Anonim, 2011). Dilüsyonlardan steril pipet ile $1 \mathrm{ml}$ alınıp, belirtilen (Tablo.3, Tablo.4) mikroorganizmalar için, gerekli ise ön zenginleştirme yap1lıp, ilgili besiyerlerine yayma plak yöntemi ile ekim yapılarak petri kapları inkübasyona bırakılmıştır. Çiğ köfte numunelerinin renk analizleri, $0,7,14$ ve 21. günlerinde kolorimetre cihazı ile (Minolta Chroma Meter CR400, Osaka, Japan) analiz edilmiş, bu analizlerde L*, $a^{*}, b^{*}$ değerlerinin ölçümü yapılmıştır (Metzger ve ark. 2008, Voss 1992).

Sonuçların istatistiksel değerlendirmesi Duncan çoklu karşılaştırma testi, IBM SPSS ver. 23.0 (2015) paket programı kullanılarak yapılmıştır (SPSS 2015).

Tablo 1. Çiğ Köftenin Formülasyonu

Table 1. Formulation of raw meatball

\begin{tabular}{ll}
\hline Hammadde & Miktar \\
\hline Bulgur & $1000 \mathrm{~g}$ \\
Kuru soğan & $600 \mathrm{~g}$ \\
Yeşil soğan & $160 \mathrm{~g}$ \\
İsot & $240 \mathrm{~g}$ \\
Salça & 200 \\
Tuz & $20 \mathrm{~g}$ \\
Karabiber & $6 \mathrm{~g}$ \\
İçme suyu & $1200 \mathrm{ml}$ \\
\hline
\end{tabular}


Tablo 2. Ekstraktlar ve oranlar1

Table 2. Extracts and ratios

\begin{tabular}{ll}
\hline Numune & Baharatlar ve seyreltme oranı \\
\hline K1 & Kontrol numunesi \\
C1 & $\%$ ''lik yeşil çay etanol ekstraktı \\
C2 & $\% 0,5$ ' lik yeşil çay etanol ekstraktı \\
D1 & $\%$ ''lik hibiskus etanol ekstrakt1 \\
D2 & $\% 0,5$ 'lik hibiskus etanol ekstraktı \\
G1 & $\% 1$ 'lik tarhun etanol ekstraktı \\
G2 & $\% 0,5$ 'lik tarhun etanol ekstraktı \\
L1 & $\%$ 1'lik ceviz kabuğu etanol ekstraktı \\
L2 & $\% 0,5$ 'lik ceviz kabuğu etanol ekstrakt1 \\
M1 & $\% 1$ 'lik limon kabuğu yağ1 etanol ekstraktı \\
M2 & $\% 0,5$ 'lik limon kabuğu yağ1 etanol ekstrakt1 \\
T1 & $\% 1$ 'lik portakal kabuğu yağ1 etanol ekstrakt1 \\
T2 & $\% 0,5$ 'lik portakal kabuğu yağ1 etanol ekstraktı \\
\hline
\end{tabular}

Tablo 3. Analizlerde kullanılan besiyerleri, inkubasyon koşulları ve kullanılan metodlar

Table 3. The Mediums Used in the Analysis, the Incubation Conditions and the Methods Used.

\begin{tabular}{|c|c|c|c|}
\hline Mikroorganizma & Besiyeri & İnkübasyon Koşulları & Kullanılan Kaynak \\
\hline $\begin{array}{l}\text { Toplam Aerobik } \\
\text { Mezofilik Bakteri }\end{array}$ & $\begin{array}{l}\text { Plate Count Agar (Merck } \\
1.05463 \text { ) }\end{array}$ & $30^{\circ} \mathrm{C}-48 / 72$ saat- aerobik & ISO 4833 (Anonymous 2003) \\
\hline $\begin{array}{l}\text { Toplam Aerobik } \\
\text { Psikrofilik bakteri }\end{array}$ & $\begin{array}{l}\text { Plate Count Agar (Merck } \\
1.05463)\end{array}$ & $4^{\circ} \mathrm{C}-5 / 7$ gün-aerobik & $\mathrm{FAO}$ \\
\hline Lactobacillus spp. & $\begin{array}{l}\text { MRS (Man Rogasa) Agar } \\
\text { (Merck 1.10661) }\end{array}$ & $30^{\circ} \mathrm{C}-24 / 48$ saat-anaerobik & ISO 15214 (Anonymous 1998) \\
\hline Lactococcus spp. & M17 Agar (Merck 1.15108) & $\begin{array}{l}30^{\circ} \mathrm{C}-24 / 48 \text { saat- } \\
\text { anaerobik }\end{array}$ & Corroler et al(Corroler et al 1998) \\
\hline Küf / Maya & $\begin{array}{l}\text { Potato Dextose Agar (Merck } \\
\text { 1.10130) }\end{array}$ & $22^{\circ} \mathrm{C}-4 / 5$ gün -aerobik & Pichhardt 1993 \\
\hline $\begin{array}{l}\text { Toplam } \\
\text { Grubu }\end{array}$ & $\begin{array}{l}\text { Violet Red Bile Agar (Merck } \\
\text { 1.01406) }\end{array}$ & $30^{\circ} \mathrm{C}-24 / 48$ saat/ aerobik & ISO 4832 (Anonymous 1991a) \\
\hline Staphylococcus aureus & $\begin{array}{l}\text { Baird Parker Agar (Merck } \\
\text { 1.05406) }\end{array}$ & $37^{\circ} \mathrm{C}-24 / 48$ saat/ aerobik & ISO 6888-1(Anonymous 1991b) \\
\hline Pseudomonas spp. & $\begin{array}{l}\text { Pseudomonas Selective Agar } \\
\text { Base (PSA) (Merck 1.07620) }\end{array}$ & $37^{\circ} \mathrm{C}-24 / 48$ saat- aerobik & ISO 13720 (Anonymous 2010) \\
\hline Esherichia coli & $\begin{array}{l}\text { Chromocult TBX Agar (Merck } \\
\text { 1.16122) }\end{array}$ & $44^{\circ} \mathrm{C}^{\prime}-24 / 48$ saat & $\begin{array}{l}\text { ISO-16649-1 (Anonymous 2001a) } \\
\text { ISO-16649-2 (Anonymous 2001b) } \\
\text { ISO-16649-3 (Anonymous 2015 }\end{array}$ \\
\hline
\end{tabular}

TAMB: Total Aerobic Mesophilic Bacteria, TAPB: Total Aerobic Psychrophilic Bacteria 
Tablo 4. Analizlerde kullanılan ön zenginleştirme broth'ları, inkubasyon koşulları ve kullanılan metodlar

Table 4. Pre-Enrichment Broths Used in The Analyzes, Incubation Conditions and Methods Used.

\begin{tabular}{|c|c|c|c|c|}
\hline Mikroorganizmalar & Besiyeri & Supplament & İnkübasyon koşulları & Kullanılan kaynak \\
\hline Listeria spp. & $\begin{array}{l}\text { Oxford (Merck 1.07004) } \\
\text { Palcam (Merck 1.11755) }\end{array}$ & $\begin{array}{l}\text { PLSS (Merck } \\
1.12122)\end{array}$ & $37^{\circ} \mathrm{C}-24 / 48$ saat- aerobik & $\begin{array}{l}\text { ISO 11290-1:2017 } \\
\text { (Anonymous 2017b) } \\
\text { ISO 11290-2:2017 } \\
\text { (Anonymous 2017c ) }\end{array}$ \\
\hline Salmonella spp . & $\begin{array}{l}\text { BPLS (Merck 1.07232) } \\
\text { XLD (Merck 1.05287) }\end{array}$ & ---- & $37^{\circ} \mathrm{C}-24 / 48$ saat- aerobik & $\begin{array}{l}\text { ISO 6579-1:2017 } \\
\text { (Anonymous 2017a) }\end{array}$ \\
\hline
\end{tabular}

PLSS: Palcam Listeria Selective Supplament acc. to van Netten et al. BPLS: Brillant-Green Phenol-red Lacoste Sucrose.

XLD: Xylose Lysine Deoxycholate.

\section{BULGULAR}

Toplam Aerobik Mezofilik Bakteri Sayısı (TAMB) Depolama süresince örneklerde Toplam aerobik mezofilik bakteri sayısındaki değişim Tablo 5'de gösterilmiştir.

\section{Maya - küf sayıs1}

Depolama süresince örneklerde maya - küf sayısındaki değişim Tablo 6'da gösterilmiștir.

\section{Pseudomonas say1s1}

Depolama süresince örneklerde Pseudomonas sayısı değişimi Tablo 7'de gösterilmiştir.

\section{Laktik asit bakterileri sayısı}

Depolama süresince örneklerde laktik asit bakterileri sayısındaki değişimi Tablo 8'de gösterilmiştir.

\section{Lactococcus cinsi bakteri sayıs1}

Depolama süresince örneklerde Lactococcus cinsi bakteri sayısındaki değişimi Tablo 9'da gösterilmiştir.

\section{Diğer mikroorganizmalar}

Depolama süresince numunelerin tümünde Salmonella spp., Listeria spp., Escherichia coli, Stapbylococcus aureus, toplam koliform grubu bakteri ve toplam aerobik psikrofilik cinsi bakterilerde üreme tespit edilememiştir.

Tablo.5. Toplam aerobik mezofilik bakteri sayısının depolama süresince değişimi (log kob/g)

Table.5. Throughout the storage period number of the Total aerobic mesophilic bacteria $(\log \mathrm{cfu} / \mathrm{g})$

\begin{tabular}{lllll}
\hline Numune & $\mathbf{0 . G u ̈ n}$ & 7.Gün & 14.Gün & 21.Gün \\
\hline K1 & $5,83 \mathrm{Ba}$ & $5,90 \mathrm{Aba}$ & $6,37 \mathrm{Aba}$ & $6,78 \mathrm{Aa}$ \\
C1 & $5,65 \mathrm{Aa}$ & $5,00 \mathrm{ABab}$ & $4,81 \mathrm{Bcd}$ & $4,64 \mathrm{Bc}$ \\
$\mathbf{C 2}$ & $5,72 \mathrm{Aa}$ & $5,20 \mathrm{ABab}$ & $4,89 \mathrm{Bc}$ & $4,56 \mathrm{Bc}$ \\
D1 & $5,92 \mathrm{ABb}$ & $4,81 \mathrm{Bcd}$ & $4,65 \mathrm{Bc}$ \\
$\mathbf{D 2}$ & $5,68 \mathrm{Aa}$ & $4,76 \mathrm{Bcd}$ & $4,46 \mathrm{Bc}$ \\
$\mathbf{G 1}$ & $5,79 \mathrm{Aa}$ & $4,15 \mathrm{ABab}$ & $4,63 \mathrm{Bd}$ & $4,60 \mathrm{Bc}$ \\
$\mathbf{G 2}$ & $5,77 \mathrm{Aa}$ & $4,68 \mathrm{Bc}$ & $4,85 \mathrm{Bcd}$ & $4,61 \mathrm{Bc}$ \\
$\mathbf{L 1}$ & $5,83 \mathrm{Aa}$ & $4,86 \mathrm{Bcd}$ & $4,78 \mathrm{Bc}$ \\
$\mathbf{L 2}$ & $5,80 \mathrm{Aa}$ & $4,89 \mathrm{Bb}$ & $4,92 \mathrm{Bc}$ & $4,87 \mathrm{Bc}$ \\
M1 & $5,90 \mathrm{Aa}$ & $5,04 \mathrm{ABab}$ & $4,85 \mathrm{Bcd}$ & $4,60 \mathrm{Cc}$ \\
M2 & $5,72 \mathrm{Aa}$ & $5,23 \mathrm{ABab}$ & $4,94 \mathrm{Bc}$ & $4,75 \mathrm{Cc}$ \\
T1 & $5,87 \mathrm{Aa}$ & $5,34 \mathrm{ABab}$ & $5,90 \mathrm{Ab}$ & $5,91 \mathrm{Ab}$ \\
T2 & $5,78 \mathrm{Aa}$ & $5,89 \mathrm{Aa}$ & $5,92 \mathrm{Ab}$ & $5,96 \mathrm{Ab}$ \\
\hline
\end{tabular}

A, B, $(\rightarrow)$ : Aynı satırda büyük farklı harflerle gösterilen değerler birbirinden $\mathrm{p}<0,05$ düzeyinde farklıdır. a, b, c, d $(\downarrow)$ : Aynı sütunda farklı harflerle gösterilen değerler birbirinden $\mathrm{p}<0,05$ düzeyinde farklıdır. 
Tablo.6. Maya-küf sayısının depolama süresince değişimi (log kob/g)

Table.6. Throughout the storage period number of the yeast / mold (log cfu/g)

\begin{tabular}{|c|c|c|c|c|}
\hline Numune & 0.Gün & 7.Gün & 14.Gün & 21.Gün \\
\hline K1 & 6,39Aa & $6,55 \mathrm{Aa}$ & 6,83Aa & 6,91Aa \\
\hline C1 & 6,30Aa & $4,26 \mathrm{Bb}$ & 3,73Cc & $2,49 \mathrm{Dc}$ \\
\hline $\mathrm{C} 2$ & $6,37 \mathrm{Aa}$ & $4,40 \mathrm{Bb}$ & $3,80 \mathrm{Cc}$ & $2,95 \mathrm{Dc}$ \\
\hline D1 & $6,11 \mathrm{Aa}$ & $5,60 \mathrm{Bab}$ & $4,60 \mathrm{Cb}$ & $4,58 \mathrm{Cb}$ \\
\hline D2 & $6,15 \mathrm{Aa}$ & $5,60 \mathrm{Bab}$ & $4,52 \mathrm{Cb}$ & $4,45 \mathrm{Cb}$ \\
\hline G1 & $6,32 \mathrm{Aa}$ & 6,37Aa & $3,67 \mathrm{Bc}$ & $2,18 \mathrm{Cc}$ \\
\hline G2 & 6,37Aa & $4,20 \mathrm{Bb}$ & $3,77 \mathrm{Cc}$ & $2,79 \mathrm{Dc}$ \\
\hline L1 & $6,00 \mathrm{Aa}$ & $4,45 \mathrm{Bb}$ & $3,68 \mathrm{Cc}$ & $2,80 \mathrm{Dc}$ \\
\hline L2 & $6,15 \mathrm{Aa}$ & $4,56 \mathrm{Bb}$ & $3,78 \mathrm{Cc}$ & $2,87 \mathrm{Dc}$ \\
\hline M1 & $6,37 \mathrm{Aa}$ & $5,37 \mathrm{Bab}$ & $4,45 \mathrm{Cb}$ & $4,54 \mathrm{Cb}$ \\
\hline M2 & 6,39Aa & $5,78 \mathrm{Bab}$ & $4,78 \mathrm{Cb}$ & $4,80 \mathrm{Cb}$ \\
\hline T1 & $6,11 \mathrm{Aa}$ & $4,58 \mathrm{Bb}$ & $3,81 \mathrm{Cbc}$ & $2,90 \mathrm{Dc}$ \\
\hline T2 & $6,26 \mathrm{Aa}$ & 4,89Bb & $3,95 \mathrm{Cbc}$ & $2,99 \mathrm{Dc}$ \\
\hline
\end{tabular}

A, B, C, D $(\rightarrow)$ : Aynı satırda büyük farklı harflerle gösterilen değerler birbirinden $\mathrm{p}<0,05$ düzeyinde farklıdır.

a, b, c, $(\downarrow)$ : Aynı sütunda farklı harflerle gösterilen değerler birbirinden $\mathrm{p}<0,05$ düzeyinde farklıdır.

Tablo 7. Pseudomonas bakteri sayısının depolama süresi boyunca değişimi $(\log \mathrm{kob} / \mathrm{g})$

Table 7. Throughout the storage period number of the Psendomonas spp. (log cfu/g)

\begin{tabular}{|c|c|c|c|c|}
\hline Numune & 0.Gün & 7.Gün & 14.Gün & 21.Gün \\
\hline K1 & $5,81 \mathrm{Aa}$ & $5,83 \mathrm{Aa}$ & $5,86 \mathrm{Aa}$ & $5,86 \mathrm{Aa}$ \\
\hline C1 & $5,76 \mathrm{Aa}$ & 5,11Aa & 4,93ABab & $4,83 \mathrm{Bb}$ \\
\hline $\mathrm{C} 2$ & $5,80 \mathrm{Aa}$ & $5,18 \mathrm{Aa}$ & 4,94ABab & 4,88Bab \\
\hline D1 & $5,80 \mathrm{Aa}$ & $4,93 \mathrm{ABb}$ & $4,87 \mathrm{Bb}$ & $4,72 \mathrm{Bb}$ \\
\hline D2 & $5,78 \mathrm{Aa}$ & $4,93 \mathrm{ABb}$ & 4,90ABab & $4,81 \mathrm{Bb}$ \\
\hline G1 & $5,80 \mathrm{Aa}$ & $5,78 \mathrm{Aa}$ & $4,97 \mathrm{Bab}$ & 4,94Bab \\
\hline G2 & $5,81 \mathrm{Aa}$ & $5,80 \mathrm{Aa}$ & $4,98 \mathrm{Bab}$ & 4,96Bab \\
\hline L1 & $5,73 \mathrm{Aa}$ & $5,00 \mathrm{Aa}$ & 4,91ABab & $4,81 \mathrm{Bb}$ \\
\hline L2 & $5,76 \mathrm{Aa}$ & $5,08 \mathrm{Aa}$ & 4,94ABab & $4,86 \mathrm{Bb}$ \\
\hline M1 & $5,56 \mathrm{Aa}$ & $4,86 \mathrm{Bb}$ & $4,79 \mathrm{Bb}$ & $4,70 \mathrm{Bb}$ \\
\hline M2 & $5,68 \mathrm{Aa}$ & $4,93 \mathrm{ABb}$ & 4,90ABab & $4,86 \mathrm{Bb}$ \\
\hline T1 & $5,72 \mathrm{Aa}$ & $4,99 \mathrm{Ba}$ & 4,93Bab & 4,90Bab \\
\hline T2 & $5,80 \mathrm{Aa}$ & $5,20 \mathrm{Aa}$ & $4,95 \mathrm{ABab}$ & $4,85 \mathrm{Bb}$ \\
\hline
\end{tabular}

A, B, $(\rightarrow)$ : Aynı satırda büyük farklı harflerle gösterilen değerler birbirinden $\mathrm{p}<0,05$ düzeyinde farklıdır.

a, b, $(\downarrow)$ : Aynı sütunda farklı harflerle gösterilen değerler birbirinden $\mathrm{p}<0,05$ düzeyinde farklıdır. 
Tablo 8. Laktik asit bakteri sayısının depolama süresi boyunca değişimi (log kob/g)

Table 8. Throughout the storage period number of the Lactic acid bacteria (log cfu/g)

\begin{tabular}{|c|c|c|c|c|}
\hline Numune & 0.Gün & 7.Gün & 14.Gün & 21.Gün \\
\hline K1 & $5,67 \mathrm{Ba}$ & $5,78 \mathrm{Aba}$ & $5,94 \mathrm{Aa}$ & 6,11Aa \\
\hline C1 & $5,61 \mathrm{Aa}$ & $5,50 \mathrm{Aa}$ & $4,83 \mathrm{Bb}$ & $4,66 \mathrm{Bb}$ \\
\hline C2 & $5,67 \mathrm{Aa}$ & $5,66 \mathrm{Aa}$ & $4,87 \mathrm{Bb}$ & $4,78 \mathrm{Bb}$ \\
\hline D1 & $5,11 \mathrm{Aa}$ & $4,63 \mathrm{Bb}$ & $4,45 \mathrm{Bb}$ & $4,18 \mathrm{Bb}$ \\
\hline D2 & $5,51 \mathrm{Aa}$ & $4,76 \mathrm{Bb}$ & $4,51 \mathrm{Bb}$ & $4,39 \mathrm{Bb}$ \\
\hline G1 & $5,58 \mathrm{Aa}$ & $5,53 \mathrm{Aa}$ & $4,93 \mathrm{Bb}$ & $4,61 \mathrm{Bb}$ \\
\hline G2 & $5,64 \mathrm{Aa}$ & $5,60 \mathrm{Aa}$ & $4,97 \mathrm{Bb}$ & $4,72 \mathrm{Bb}$ \\
\hline L1 & $5,66 \mathrm{Aa}$ & $5,61 \mathrm{Aa}$ & $4,83 \mathrm{Bb}$ & $4,30 \mathrm{Bb}$ \\
\hline L2 & $5,68 \mathrm{Aa}$ & $5,65 \mathrm{Aa}$ & $4,91 \mathrm{Bb}$ & $4,69 \mathrm{Bb}$ \\
\hline M1 & $5,51 \mathrm{Aa}$ & $4,83 \mathrm{Bb}$ & $4,74 \mathrm{Bb}$ & $4,18 \mathrm{Bb}$ \\
\hline M2 & $5,58 \mathrm{Aa}$ & 4,93Bab & $4,78 \mathrm{Bb}$ & $4,51 \mathrm{Bb}$ \\
\hline T1 & $5,41 \mathrm{Aa}$ & 4,90Bab & $4,83 \mathrm{Bb}$ & $4,71 \mathrm{Bb}$ \\
\hline $\mathrm{T} 2$ & $5,53 \mathrm{Aa}$ & 4,93Bab & $4,87 \mathrm{Bb}$ & $4,82 \mathrm{Bb}$ \\
\hline
\end{tabular}

A, B, $(\rightarrow)$ : Aynı satırda büyük farklı harflerle gösterilen değerler birbirinden $\mathrm{p}<0,05$ düzeyinde farklıdır.

a, b, $(\downarrow)$ : Aynı sütunda farklı harflerle gösterilen değerler birbirinden $\mathrm{p}<0,05$ düzeyinde farklıdır.

Tablo 9. Lactococcus spp. cinsi bakteri sayısı depolama süresi boyunca değişimi (log kob/g)

Table 9. Throughout the storage period number of the Lactococcus spp. (log cfu/g)

\begin{tabular}{|c|c|c|c|c|}
\hline Numune & 0.Gün & 7.Gün & 14.Gün & 21.Gün \\
\hline K1 & $3,83 \mathrm{Ba}$ & 3,99ABa & $4,52 \mathrm{Aa}$ & $4,96 \mathrm{Aa}$ \\
\hline C1 & $3,80 \mathrm{Aa}$ & $3,78 \mathrm{Ab}$ & $3,75 \mathrm{Ab}$ & $3,08 \mathrm{Bb}$ \\
\hline $\mathrm{C} 2$ & $3,83 \mathrm{Aa}$ & $3,82 \mathrm{Ab}$ & $3,77 \mathrm{Ab}$ & $3,20 \mathrm{Bab}$ \\
\hline D1 & $3,74 \mathrm{Aa}$ & $3,70 \mathrm{Ab}$ & $3,34 \mathrm{ABb}$ & $3,04 \mathrm{Bb}$ \\
\hline D2 & $3,77 \mathrm{Aa}$ & $3,72 \mathrm{Ab}$ & $3,41 \mathrm{ABb}$ & $3,28 \mathrm{Bab}$ \\
\hline G1 & $3,82 \mathrm{Aa}$ & $3,74 \mathrm{Ab}$ & $3,69 \mathrm{Ab}$ & $3,52 \mathrm{Aab}$ \\
\hline G2 & $3,80 \mathrm{Aa}$ & $3,78 \mathrm{Ab}$ & $3,70 \mathrm{Ab}$ & 3,57Aab \\
\hline L1 & $3,83 \mathrm{Aa}$ & $3,70 \mathrm{Ab}$ & $3,62 \mathrm{Ab}$ & 3,48Aab \\
\hline L2 & $3,78 \mathrm{Aa}$ & $3,78 \mathrm{Ab}$ & $3,72 \mathrm{Ab}$ & 3,63Aab \\
\hline M1 & $3,77 \mathrm{Aa}$ & $3,64 \mathrm{Ab}$ & $3,50 \mathrm{Ab}$ & 3,41Aab \\
\hline M2 & $3,81 \mathrm{Aa}$ & $3,76 \mathrm{Ab}$ & $3,63 \mathrm{Ab}$ & 3,50Aab \\
\hline T1 & $3,80 \mathrm{Aa}$ & $3,71 \mathrm{Ab}$ & $3,50 \mathrm{Ab}$ & $3,20 \mathrm{Bab}$ \\
\hline $\mathbf{T} 2$ & 3,81Aa & $3,80 \mathrm{Ab}$ & $3,62 \mathrm{Ab}$ & $3,34 \mathrm{Aab}$ \\
\hline
\end{tabular}

A, B, $(\rightarrow)$ : Aynı satırda büyük farklı harflerle gösterilen değerler birbirinden $\mathrm{p}<0,05$ düzeyinde farklıdır.

a, b, $(\downarrow)$ : Aynı sütunda farklı harflerle gösterilen değerler birbirinden $\mathrm{p}<0,05$ düzeyinde farklıdır. 


\section{Renk Analizleri}

\section{L* Değerindeki değişmeler}

Çĭ̆ köfte numunelerinde depolama süresince $L^{*}$ değerleri

Tablo.10’ da gösterilmiştir.

Tablo 10.Depolama süresi boyunca $L^{*}$ değerindeki değişimler

Table 10. Changes in $\mathrm{L} *$ value over the storage time

\begin{tabular}{ccccc}
\hline Numune & 0.Gün & 7.Gün & 14.Gün & 21.Gün \\
\hline K1 & 37,35 & 40,49 & 38,91 & 40,32 \\
C1 & 36,94 & 37,85 & 38,65 & 39,74 \\
C2 & 36,53 & 38,88 & 39,91 & 39,14 \\
D1 & 36,20 & 39,95 & 39,06 & 39,24 \\
D2 & 35,41 & 38,09 & 38,10 & 39,77 \\
G1 & 38,04 & 39,90 & 39,78 & 39,96 \\
G2 & 37,66 & 39,50 & 39,40 & 40,60 \\
L1 & 36,94 & 37,93 & 39,23 & 40,27 \\
L2 & 36,63 & 37,81 & 40,12 & 41,06 \\
M1 & 33,99 & 39,35 & 38,46 & 40,05 \\
M2 & 36,49 & 39,26 & 39,10 & 39,59 \\
T1 & 35,83 & 38,29 & 39,16 & 40,36 \\
T2 & 37,04 & 39,82 & 39,39 & \\
\hline
\end{tabular}

\section{a* Değerindeki değişmeler}

Çiğ köfte numunelerinde depolama süresince $a^{*}$ değerleri

Tablo.11'de gösterilmiştir.

Tablo 11.Depolama süresi boyunca $a^{*}$ değerindeki değişimler

Table 11. Changes in $a^{*}$ value over the storage time

\begin{tabular}{ccccc}
\hline Numune & 0.Gün & 7.Gün & 14.Gün & 21.Gün \\
\hline K1 & 37,35 & 40,49 & 38,91 & 40,32 \\
C1 & 36,94 & 37,85 & 38,65 & 39,74 \\
C2 & 36,53 & 38,88 & 39,91 & 39,14 \\
D1 & 36,20 & 39,95 & 39,06 & 39,24 \\
D2 & 35,41 & 38,09 & 38,10 & 39,77 \\
G1 & 38,04 & 39,90 & 39,78 & 38,96 \\
G2 & 37,66 & 39,50 & 39,40 & 39,03 \\
L1 & 36,94 & 37,93 & 39,23 & 40,60 \\
L2 & 36,63 & 37,81 & 40,12 & 40,27 \\
M1 & 33,99 & 39,35 & 38,46 & 41,06 \\
M2 & 36,49 & 39,26 & 39,10 & 40,05 \\
T1 & 35,83 & 38,29 & 39,16 & 39,59 \\
T2 & 37,04 & 39,82 & 39,39 & 40,36 \\
\hline
\end{tabular}




\section{b Değerindeki değişmeler}

Çiğ köfte numunelerinde depolama süresince $b^{*}$ değerleri

Tablo.12' de gösterilmiştir.

Tablo 12. Depolama Süresi Boyunca b* değerindeki değişimler

Table 12. Changes in $b^{*}$ value over the storage time

\begin{tabular}{ccccc}
\hline Numune & 0.Gün & 7.Gün & 14.Gün & 21.Gün \\
\hline K1 & 22,40 & 27,95 & 25,25 & 27,08 \\
C1 & 24,44 & 24,14 & 24,79 & 27,94 \\
C2 & 21,77 & 25,91 & 25,54 & 25,94 \\
D1 & 19,10 & 27,17 & 25,36 & 27,13 \\
D2 & 20,72 & 23,80 & 23,35 & 26,31 \\
G1 & 22,13 & 26,97 & 24,67 & 27,49 \\
G2 & 20,97 & 23,90 & 25,68 & 26,80 \\
L1 & 21,21 & 22,78 & 24,92 & 32,14 \\
L2 & 21,22 & 23,53 & 26,29 & 28,88 \\
M1 & 23,13 & 25,25 & 25,15 & 28,07 \\
M2 & 20,01 & 24,41 & 24,61 & 28,73 \\
T1 & 20,33 & 24,23 & 25,50 & 29,48 \\
T2 & 19,56 & 25,02 & 23,68 & \\
\hline
\end{tabular}

\section{TARTIŞMA}

Yapılan analizler sonucunda \%1 oranında yeşil çay etanol ekstraktının, Lactococcus spp. cinsi bakteriler üzerinde en etkili ekstrakt olduğu; \%0,5 oranında ilavesinin ise, çalışmada kullanılan diğer ekstraktlara göre, toplam aerobik mezofilik bakteri sayısında en etkili bitki ekstraktı olduğu tespit edilmiştir.

Çalışmamızda elde ettiğimiz sonuçlara benzer şekilde, Velioğlu (2007), yeşil çayın antimikrobiyal etkisini araştırdığı bir çalışmasında, antimikrobiyal etkinin kullanılan ekstrakt konsantrasyonu ile ilgili olduğunu vurgulamış ve fermente olmamış çayların antimikrobiyal aktivitesinin; fermente olan çaylara göre daha yüksek olduğunu belirtmiştir. Ayrıca bu antimikrobiyal etkinin, çay yapraklarında bulunan kateşinlerden kaynaklandığını ortaya koymuştur.

Amarowicz ve ark. (1996) tarafindan yapılan başka bir çalışmada ise yeşil çay polifenollerinin Escherichia Coli K12 suşuna karşı antibakteriyel etkisinin olduğu raporlanmıştır.

Kullanılan diğer bir ekstrakt olan hibiskus etanol ekstraktının \%1 oranında ilavesinin Pseudomonas, Lactobacillus spp. ve Lactococcus spp. cinsi bakteri sayısında; \%0,5 oranında ilavesinin ise toplam aerobik mezofilik bakteri sayısında azalmaya neden olduğu saptanmıştır.

Çömlekçioğlu ve ark. (2014) bazı bitki ekstraktlarının antimikrobiyal aktivitelerinin belirlenmesi üzerine yapmış oldukları çalısmanın sonuçları, analizlerimizi doğrular nitelikte olup, hibiskus bitkisinden elde olunan ekstraktların antimikrobiyal yönünün kuvvetli etki gösterdiği bulgularını ortaya koymuştur. Depolama süresi boyunca çĭ̆ köfte numunelerinin maya/ küf sayısının azalmasında en etkili ekstrakt \%1 oranında ilave edilen tarhun ekstraktı olmuştur.

Tarhun bitkisinin antimikrobiyal özelliklerinin de incelendiği bir çalışmada, bu bitkinin uçucu yağlarının antimikrobiyal aktiviteye sahip olduğu tespit edilmiştir. (Tüylü ve ark. 2009).

Çiğ köfte numunelerinin, depolama süresi boyunca tümünde Psendomonas cinsi bakteri sayllarında bir azalma görülmüş olmasına karşın; \%1 oranında ilave edilen limon kabuğu yağı, kullanılan diğer ekstraktlara göre bu bakteri cinsinde daha yüksek antimikrobiyal etki göstermiştir. Limon kabuğu yağının etki gösterdiği diğer bir mikroorganizma ise Lactobacillus lactis olarak tespit edilmiştir.

Çoksever (2009) tarafından yapılan bir araştırmada limon ekstraktının antimikrobiyal etkileri incelenmiş ve sadece Lactobacillus lactis üzerine etki gösterdiği tespit edilmiştir. Bu sonuç, çalısmamızın doğruluğunu kanıtlar nitelik taşımaktadır. Konu ile ilgili yapılan diğer bir çalışmada ise limon meyvesinin yağ asidi ekstraktlarının, K.pneumoniae ve Staphylococcus aureus dișında, tüm bakteri (Eschericbia Coli), maya (Candida albicans) ve funguslarnn (Epidermophyton spp.) gelişimlerini değişen 
oranlarda önlediği ortaya konmuștur. (Erecevit ve Kirbağ 2017).

Çalışmada kullanılan portakal kabuğu yağı etanol ekstraktının ise her iki oranda $(\% 1$ ve $\% 0,5)$ kullanımi, toplam aerobik mezofilik bakteri sayısının düşürülmesinde etkili olmamıştır. Kullanılan diğer bir ekstrakt olan, ceviz kabuğu etanol ekstrakt1, tüm mikroorganizma gruplar1 üzerinde belirli oranlarda antimikrobiyal etki göstermiştir.

Yiğit ve ark. (2009) yapmış oldukları çalışmada ceviz (Juglans regia L.) bitkisinin çeşitli aksamlarının su ve metanol ekstraktlarinin Staphylococcus aureus, Staphylococcus epidermidis ve Pseudomonas aeruginosa üzerinde antimikrobiyal aktiviteye sahip olduğunu belirlemişlerdir.

Oliveira ve ark (2008) tarafindan yapilan bir araştırmada yaprak aksamının su ile ekstraksiyonunun Candida albicans ve Cryptococcus neoformans üzerinde antifungal etki gösterdiği tespit edilmiştir.

Mehrabian ve ark. (2000) ise, Ceviz (Juglans regia L.) yeşil kabuk ve yaprak kısımlarından elde ettikleri ekstrelerinin antimikrobiyal özelliğini inceledikleri çalışmada aksamların metanol ekstrelerinin, etanol ekstrelerine göre daha etkili antimikrobiyal özelliğe sahip olduğunu belirtmişlerdir.

Çoksever (2009) tarafından yapılan bir çalışmada portakal kabuğundaki fenolik maddeler, metanol ile ekstrakte edilerek kullanıldığında antimikrobiyal aktivitenin yanı sıra, portakal kabuğu ekstraktının, yüksek antioksidan etkiye sahip olduğu ortaya konmuştur. Başka bir çalışmada ise portakal ekstraktinin Lactococcus lactis ile Listeria innocua üzerine etkili olduğu tespit edilmiştir. (Frazier 1980).

Çalışmamızda elde edilen bulguların Çoksever (2009) ve Frazier (1980)' in sonuçlarından farklı olmasinın nedeni, ekstraksiyon sirasinda kullanilan çözücü maddeden ve kullanılan konsantrasyon değerlerinden kaynaklanabileceği düşünülmektedir.

Analiz süresi boyunca her $0,7,14$ ve 21. günlerde çiğ köfte numunelerinin renk analizleri yapılmış, bu analizler sonucunda kontrolün $L^{*}, a^{*}$ ve $b$ değerinin zamana bağlı olarak artış gösterdiği gözlemlenmiştir. $L^{*}$ değeri; ürünün parlaklık ve koyuluğunu ifade etmektedir. (Voss 1992, Anonim 2012). Başlangıçta en yüksek $L^{*}$ değeri 38,04 (P>0,05) ile G1 numunesine ait olup, 21 gün sonunda en düşük $L^{*}$ değeri; 39,59 (P>0,05) ile T1 numunesinde görülmüştür. Baharat ekstraktı ilavesinin; G1 ve G2 numuneleri hariç, diğer tüm çĭ̆ köfte numunelerinde $L^{*}$ değerinin önce düşmesine ve daha sonra artmasina neden olmuştur. Depolama süresi sonunda en fazla değişim gösteren ve en yüksek $L^{*}$ değerine sahip numune, 41,06 ( $\mathrm{P}>0,05)$ değeri ile \%1 oranında limon kabuğu yağ1 ekstraktı içeren M1 numunesi olmuştur. Kırmızı etin depolanması ve muhafaza ömrü ile ilgili yapılan bir araştırmada limon ekstraktı kullanılmış ve $L^{*}$ değerinin düştüğü tespit edilmiştir. Bu durum limondaki su tutan bileşenin suyu absorbe etmesi ve buna bağl1 olarak $L^{*}$ değerinin düşmesi ile açıklanmıştır. (Çoksever 2009).

Çoksever (2009)' in limon kabuğu ekstraktı ile yapmış olduğu çalışma sonucu, çalışmamız ile kıyaslandığında farklı sonuçlar elde edilmesinin nedeni olarak ürün çeşidi ve kullanılan konsantrasyon miktarından kaynaklı olduğu düşünülmektedir.

Çalışmada kullanılan numunelere bitki ekstraktları ilavesinin öncesinde ve hemen sonrasinda renk analizi yapılmış, ilk sonuçlara kıyasla D2, M1 ve C1 numuneleri dişında diğer tüm ekstraktların $L^{*}$ değerinde önce bir düşüş yaşanmış, ardından zamana bağlı olarak artış gözlemlenmiştir. Diğer bir renk parametresi olan $a^{*}$ değeri; kırmızı ve yeşil renkleri ifade etmektedir. (Voss 1992; Anonim 2012).

Ekstrakt ilavesinin hemen ardından ölçüm yapılmış, $a^{*}$ değerinin M1, D2 ve C1 numunelerinde, kontrol numunesine kıyasla bir artış gözlenmiştir. Diğer numunelerde ise başlangıçta en düşük $a^{*}$ değeri 19,42 ( $\mathrm{P}>0,05)$ ile M1; depolama süresi sonunda en yüksek $a^{*}$ değerine sahip ise 21,84 ( $\left.\mathrm{P}>0,05\right)$ değeri ile D2 numunesi olmuştur. Analiz süresi boyunca, numunelerin a* değerinde genel olarak bir artış gözlemlenmiştir.

Çoksever (2009), antioksidan aktivitesi düşük olan turunçgil ekstraktlarının bulunduğu örneklerin en düşük $a^{*}$ değerine sahip olacağı kanısına karşın Higgins ve ark. (1998) yapmış olduğu analizlerde; turunçgillerde mevcut olan karotenoidlerin oksidasyonu azalttı̆̆1 ve $a^{*}$ değerini yükselttiğini ortaya koymuştur. Bu durumun çalışmamız ile olan farklılığının kullanılan hammaddeden kaynaklanabileceği öngörülmektedir. Sarı ve mavi renkteki değişimler ifade eden $b^{*}$ değerinin depolama süresi boyunca tüm çĭ̆ köfte numunelerinde arttığ1 tespit edilmiştir. Başlangıçta en düşük $b$ değeri 19,10 (P>0,05) ile D1 numunesi iken; analiz süresi sonunda en yüksek $b$ değerine sahip numune 32,14 ( $<</>0,05)$ değeri ile L2 numunesi olmuştur. 


\section{SONUÇ}

Son y1llarda tüketimi sıkça artan geleneksel gıdalarımızdan biri olan çiğ köfte, raf ömrü oldukça kısa ve mikrobiyal riski yüksek olan bir gida maddesidir. Araştırmacılar tarafindan, gıdaların raf ömrü üzerine yapılan birçok çalş̧mada, antimikrobiyal etkisi bilinen çeşitli bitkiler veya bu bitkilerin ekstraktları kullanılmıș ve oldukça önemli sonuçlar elde edilmiștir. Bu çalıșmada bazı bitki ekstraktlarının, çiğ köfte üzerindeki antimikrobiyal etkisi araştırılmış, çalışma esnasında farklı oranlarda bitki ekstraktları kullanılmışıı. Bu çalışmadan elde edilen sonuçlar, çiğ köfte üretimi sırasında, hijyen ve sanitasyon koşullarına dikkat edildiği taktirde, kullanılan bitki ekstraktlarının mikroorganizmalar üzerinde belirli oranlarda antimikrobiyal etki gösterdiğini ortaya koymuştur. Çiğ köfte üretiminde bu bitki ekstraktlarının kullanımı ile birlikte, ürünün raf ömründe artışla beraber mikrobiyal risk azalacaktır.

\section{KAYNAKLAR}

Amorowicz R, Shahidi A. Rapid Chromatographic Method For Seperation Of İndividual Catechins From Green Tea. Food Research International.1996; 29, 7176.

Anonim. Merck Mikrobiyoloji El Kitabı, Merck Mikrobiyoloji, 2.Bask1, 2011; Ankara., 234 s.

Anonim. Gida Teknolojisi. Duyusal Kontrolleri Yapma, Gidalarda Renk, T.C. Milli Eğitim Bakanllğı, Ankara 2012; 15-23.

Anonymous. ISO (Inetnational Standard Organization) 6888-1 Hortizonal Method for the Enumeration of Cogulase- positive Staphlococci Technique using Braid Parker Agar Medium. 1991a; 4-4411.

Anonymous. ISO (International Standard Organization) 4832 General Guidance fort the Enumeration of Coliforms Colony Count Technique ,1991b.

Anonymous. ISO (Inetnational Standard Organization) Microbiology of food and animal feeding stuffs -- Horizontal method for the enumeration of mesophilic lactic acid bacteria -- Colony-count technique at 30 degrees C,1998; 15214 -1998.

Anonymous. ISO (Inetnational Standard Organization) Mirobiology of food and animal feeding stuffs - Hortizonal method for the enumeration of beta-glucuronidasepositive Escherichia coli- Part 1: Colonyccount technique at 44 degrees $\mathrm{C}$ using membranes and 5-bromo-4-chloro-3-indolyl beta - D-glucuronide, 2001a; 16649-1:2001.

Anonymous. ISO (Inetnational Standard Organization) Mirobiology of food and animal feeding stuffs - Hortizonal method for the enumeration of beta-glucuronidasepositive Escherichia coli- Part 2: Colonyccount technique at 44 degrees $\mathrm{C}$ using 5bromo-4-chloro-3-indolyl beta - Dglucuronide, 2001b; 16649-2:2001.

Anonymous. ISO (International Standart Organisation) Horizontal Method for the Enumaration of Microorganism. Colony Count, Technique at 30두 4833. 2003.

Anonymous. ISO (Inetnational Standard Organization) specifies a method for the enumeation of presumptive Pseudomonas spp. Present in meat and meat products, including poultry. (pseudomonas), 2010; 13720:2010.

Anonymous. ISO (Inetnational Standard Organization), Mirobiology of food chain Hortizonal method for the enumeration of beta-glucuronidase- positive Escherichia coli- Part 3: Detection and most probable number technique using 5-bromo-4-chloro3-indolyl beta - D-glucuronide, 2015; 16649-3:2015.

Anonymous. ISO (Inetnational Standard Organization) Hortizonal method fot the detection, enumeration and serotyping of Salmonella, 2017; 6579-1:2017a.

Anonymous. ISO (Inetnational Standard Organization) Microbiology of the food chain -- Horizontal method for the detection and enumeration of Listeria monocytogenes and of Listeria spp. -- Part 1: Detection method, 2017; 11290-1:2017b.

Anonymous. ISO (Inetnational Standard Organization) Microbiology of the food chain -- Horizontal method for the detection and enumeration of Listeria monocytogenes and of Listeria spp. -- Part 2: Enumeration method, 2017; 11290-2:2017c

Arın B. Et Ürünlerinde Kullanılan Bazı Baharatların Antimikrobiyal Ve Antioksidan Aktivitelerinin İncelenmesi, Yüksek Lisans Tezi, İstanbul Teknik Üniversitesi, Fen Bilimleri Enstitüsü, İstanbul, 2009.

Arslan A, Güven A, Saltan S, Patır B. Elazı̆̆'da Tüketime Sunulan Çiğ Köftelerin Mikrobiyolojik Kalitesi. FÜ. Sağlık Bil.,Derg. 1992; 6, (1): 1318. 
Azırak S. Thymol ve Carvacrol'un İn Vivo Genotoksik Etkilerinin Araştırılması. Doktora Tezi, Çukurova Üniversitesi Fen Bilimleri Enstitüsü, Adana, 2007.

Başoğlu F. Gıdalarda Kullanılan Bazı Baharatlanın Mikroorganizmalar Üzerine Etkileri ve Kontaminasyondaki Rolleri, 1982; G1da 1: 19-24.

Bayaz M. Esansiyel Yağlar: Antimikrobiyal, Antioksidan ve Antimutajenik Aktiviteleri. Ege Üniversitesi. Akademik G1da, , Derg. 12(3), 2014; 45-53.

Coggins PC. Spices and flavourings for meat and meat products, in Meat Science and Aplications, Eds. Hui YH, Kit W, Rogers RW, Young OA. Marcel Dekker, Inc., New York, USA, 2001.

Corroler D, Mangin I, Desmasures N, Gueguen M. An ecological study of lactococci isolated from raw milk in the Camembert cheese registered designation of origin area. Appl. Environ. Microbiol. 1998; 64, 4729-4735.

Çetin ET, Aktan G . Hastalık Vektörü Olarak Eller. Kükem Derg. 1985; 8, (2): 6-8.

Çoksever E. Farklı Oranlarda Turunç Albedosu İlavesinin Sucuk Kalitesi Üzerine Etkisi, Yüksek Lisans Tezi, Selçuk Üniversitesi Fen Bilimleri Enstütüsü Konya, 2009.

Çömlekcioğlu N, Efe L, Karaman Ş. Kahramanmaraş Koşullarında Farklı Ekim Zamanlarinin Isatis tinctori ve Isatis buschiana Türlerinin Verim ve Bazı Agronomik Özellikleri Üzerine Etkileri, Tekirdağ Ziraat Fakültesi Dergisi 2014; 11(1): 67-78.

Daglioglu F, Ilaslan N, Y1lmaz I. The microbiological quality of cig kofte sold in Istanbul, Turkey. Fleiswirthschaft International, 2005; 1-10.

Erecevit P, Kırbağ S. Probiyotik Maya Olarak Saccharomyces cerevisiae'nın Gelişimine, Citrus limon (L.) Burm. f. (Limon)'un Baz1 Fitokimyasal Etkileri, Bitlis Eren Üniversitesi Fen Bilimleri Dergisi 2017; 6(2);49-61.

Erol I, Mutluer B, Vatansever L. A Tipi Enterotoksin Oluşturan Staphylococcus aureus'un Çĭ̆ Köftede Üreme ve Toksin Oluşturma Yeteneğinin Belirlenmesi, 1993; G1da 18, (5): 315-318.

FAO. Manual of Food Quality Control. "Microbiological Analysis". Food and Agricultural Organization of the United Nations Rome, 1992; 4. Rev. 1, 43-56.
Frazier SF. Antimicrobial composition of matter from naturally occurring flavonoid glycosides. 1980; US Pat. 4, 238-483.

Fullerton M, Khatiwada J, Johnson JU, Davis S, Williams LL. Determination of Antimicrobial Activity of Sorrel (Hibiscus sabdariffa) on Esherichia coli O157:H7 Isolated from Food, Veterinary, and Clinical Samples, Journal Of Medicinal Food, 2011; 14 (9), 950-956.

Gezgin Z. Gama Işınlarının Çiğ Köftenin Mikrobiyal Güvenliği Ve Kalitesine Etkileri, Yüksek Lisans Tezi, İstanbul Teknik Üniversitesi Fen Bilimleri Enstitüsü, İstanbul, 2005.

Higgins, FM, Kerry JP, Buckley DJ, Morrisey PA. Effect of dietary a-tocopheryl acetate supplementation on a-tocopherol distribution in raw turkey muscles and its effect on the storage stability of cooked turkey meat. Meat Sci., 1998; 37, 373-383.

Karakoç ÖC, Gökçe A. Farklı bitki ekstraktlarının Spodoptera littoralis (Lepidoptera: Noctuidae) üzerinde beslenme engelleyici ve mide zehiri etkileri, Türk. Entomol, Derg., 2013; 37 (1): 73-80.

Karanki E. Ülkemizde Yaygın Olarak Kullanılan Bazı Baharatların Antimikrobiyal Aktivitesinin Belirlenmesi. Yüksek Lisans Tezi, Niğde Üniversitesi, Fen Bilimleri Enstitüsü, Niğde, 2013.

Keskin S, Akarca G, Şin E. Taze Çay Yapraklarının Antimikrobiyal Etkisi. II. Uluslararası Turizm Ve Mikrobiyal Gida Güvenliği, 13-14 Aralık, Akdeniz Üniversitesi, Antalya, 2017.

Koca İ, Bostancı Ş. Çayın Antimikrobiyal Aktivitesi, 4.Gıda Güvenliği Kongresi, Harbiye Askeri Müze ve Kültür Sitesi, 1, İstanbul, 2013.

Mehrabian S, Majd A, Majd I. Antimicrobial eff ects of three plants (Rubai tinctorum, Carthamus tinctorius and Juglans regia) on some airbone microorganisms. Aerobiologia 2000; 16:455-58

Metzger, LE, Barbano DM, Rudan MA, Kindstedt PS, Guo MR. Whiteness Change During Heating and Cooling of Mozzarella Cheese. Journal of Dairy Science, 2008; 83: $1-10$.

Oliveira I, Sousa A. CFR Isabel et al. Total phenols, antioxidant potential and antimicrobial activity of walnut (Juglans regia 
L.) green husks. Food Chem Toxicol 2008; doi:10.1016/j. fct.2008.03.017.

Öcal MH. Özellikleri ve Güzellikleriyle Çiğ Köftemiz. Özlem Kitabevi, Şanlıurfa, 1997.

Pichhardt K. Lebensmittelmikrobiologie. 3. Auflage. Springer Verlag, Berlin, New York, Paris, Tokyo, London, Hong Kong, Barcelona, Budapest, 1993.

Plotto A, Mazaud F, Röttger A, Steffel K. Hibiscus Post-harvest Operations, Food and Agriculture Organization of the United Nations (FAO), 2004.

Sağun E, Sancak YC, Durmaz H, Akkaya L. Van'da Tüketime Sunulan Çĭğ Köftelerin Hijyenik Kaliteleri Üzerine Bir Araştırma. YYÜ. Sağ., Bil. Derg.1997a ; 3, (1): 64-67.

Sağun E, Sancak YC, Durmaz H, Ekici K. Gidalarda Kullanılan Bazı Baharatların Mikrobiyolojik Kalitesi. YYÜ. Vet. Fak. Derg., 1997b; 8, (1-2): 1-5.

Seçkin Y, Karagözlü N. Gıda Mikrobiyolojisi. Gıda Endüstrisi İçin Temel Esaslar ve Uygulamalar. Klaus Pichhardt. (4.Basimdan Çeviri). Literatür Yayıncılık. İstanbu, 2004.

Şen, C. Hibiskus sabdariffa L. bitkisinin Antimikrobiyal Ve Antioksidan Etkisinin Araştırılması, Yayınlanmamış Yüksek Lisans Tezi,Trakya Üniversitesi Fen Bilimleri Enstitüsü, 2011.

Tekinşen OC, Yurtyeri A, Mutluer B. Bacteriological quality of ground meat in Ankara, A.U. Vet. Fac. J. , 1980; 27, 45.

Tunçel G, Tiryaki G. Çiğ köftelerin gıda güvenliği açısından değerlendirilmesi. Dünya Gıda, 2001; (12): 56-61 .

Tüylü BA, Yilmaz M, Kivanc M. Study on the antumicrobial, cytotoxic, and genotoxic activities of the essential oil of artemisia dracunculus l., feb - Fresenius Environmental Bulletin. by PSP, 2009, Volume 18 - No 5b., 889-893.

Velioğlu, S. Farklı Çay ekstraktlarının antioksidan, antibakteriyal etkileri ve fenolik madde dagilımının HPLC ile belirlenmesi, Ankara Üniversitesi Bilimsel Araştırma Projeleri, Ankara, 2007, 1-23.

Voss, DH. Relating Colorimeter Measurement of Plant Color to the Royal Horticultural Society Colour Chart. Hortscience, 1992; 27.(12):1256-1260.

Yiğit D, Yiğit N, Aktaş E, Özgen U. Ceviz (Juglans Regra L.)'In Antimikrobiyal
Aktivitesi, Türk Mikrobiyol Cem Derg 2009; 39 (1-2): 7-11. 